\title{
Rawa Pening and the Surrounding: A Study of Environmental Determinism
}

\author{
Kun Muhammad Delvin Adhiguna ${ }^{1 *}$, Afidatul Lathifah ${ }^{2}$, and Eko Punto Hendro ${ }^{3}$ \\ ${ }^{1}$ Department of Social Anthropology, Faculty of Humanities, Diponegoro University, Indonesia \\ ${ }^{2}$ Department of Social Anthropology, Faculty of Humanities, Diponegoro University, Indonesia \\ ${ }^{3}$ Department of Social Anthropology, Faculty of Humanities, Diponegoro University, Indonesia
}

\begin{abstract}
Rawa Pening Lake is one of the landscapes in Semarang Regency. The existence of the lake has social, cultural, and economic impacts on the people who live around it, giving rise to a pattern of relationships between humans and nature. The relationship pattern between Lake Rawa Pening and the surrounding community is studied in terms of environmental determinism, that the environment shapes the culture and characteristics of the surrounding society Environmental determinism provides a scientific foundation to see how society lives and to see the society's mindset that is formed as a result of the pattern of human relations with nature. This research also focuses on the community's meaning of Lake Rawa Pening. The method used in this research is qualitative and data collection techniques with in-depth interviews, participant observation, documentation, and literature study. The research was conducted in Bejalen Village, Ambarawa District, Semarang Regency. The results of interviews and literature studies show that there are several patterns of community relations with Lake Rawa Pening such as livelihoods by region, livelihood by groups, work equipment, local knowledge, and traditions
\end{abstract}

\section{Introduction}

Humans live and utilize natural and environmental products for their survival; there was a pattern of relations between the environment and humans during that time. The pattern of environmental relations with humans is studied in terms of environmental determinism. Environmental determinism is a set of ideas introduced by Ellen C. Semple from Friederich Ratzel's interpretation of the nature-culture relationship [5]. Environmental determinism argues that the natural environment is responsible for all human actions [6]. The environmental determinism framework allows for a linkage between climatic conditions and other aspects of the physical environment with everything from culture, regional character, a political organization to the rise of civilization [5]. Further explanation to explain the thought of environmental determinism is a factor that influences the support of a society's prosperity, namely geographical and environmental conditions and also the belief that the environment (landscape or climate) determines human cultural patterns and

\footnotetext{
${ }^{*}$ Corresponding author: kundelvin88@gmail.com
} 
community development [9]. Environmental determinism also explains the community's character as seen from the environment they live in [4].

Experts, both anthropologists and geographers, have carried out studies about environmental determinisms. Such as Marvin Harris, who researched the prohibition of pork on environmental sustainability in Muslim and Jewish communities. Marvin Harris is the originator of cultural materialism and tries to answer why pigs were forbidden in Muslim and Jewish societies at that time. Muslims and Jews are descendants of the prehistoric Hebrews (mid-2nd century AD). They live in rough, hot, arid places and live in the river valleys of Mesopotamia and Egypt. The people at that time also had a nomadic life habit. Animals that can be relied on with such living habits are goats, cows, and sheep, while pigs will be difficult to rise because they cannot move from place to place. When viewed from the place where they live, according to research by LE Mount from the agricultural Council Institute of Animal Psychology in Cambridge, adult pigs will die if exposed to direct sunlight, and the air temperature is above $37 \mathrm{o}$, so it will be tough for pigs to adapt to the habitation of Muslim and Jews. Temperature above 43o. Pigs are omnivorous animals; their nutritional needs are obtained from grass such as cows, goats, sheep and tubers, nuts, fruits, and human needs. With the barren and dry natural conditions, it will be tough to meet the food need of pigs which are the same as the food needs of humans [10].

Michael Dove has conducted subsequent research regarding Mount Merapi, which forms the habits and mindset of the Turgo Village community, especially on the domestication of volcanic hazards and eruptions as agents of change. A volcanic eruption is a dangerous natural disaster and has a significant impact on the surrounding environment. In the case of Mount Merapi, volcanic eruptions have claimed many lives and damaged villages. However, residents domesticated the eruption hazard for economic adaptation to the volcanic environment, especially on the grass to feed livestock and volcanic ash from the eruption helped residents eradicate pests (Imperata Cylindrica). Villagers also believe the eruption was the result of the one sure night cleaning. The existence of domestication of volcanic hazards by villagers makes residents naturalize and take advantage of volcanic disturbances for the agricultural economy, causing a culture of volcanic hazards. Fruiting agents, which are the impact of the eruption, are changing jobs from cultivating food crops for their own needs to producing market needs. Since the eruption, Turgo Village has become a regional mil producer. The average villager has an annual income that is almost equal to or greater than the national average. This can be seen in the increase in home improvement with walled houses from 1987 by $20 \%$ to $50 \%$ until 2008 . Residents also added glass, electricity, tiled floors, and plaster walls [3].

Bejalen village is one of the villages located on the coast of Lake Rawa Pening. Bejalen village is located in Ambarawa District, Semarang Regency. Bejalen Village has an area of approximately 470,720 hectares, with the northern borders of Lodoyong, Kupang, and Tambak Boyo Villages; the south is Banyubiru Village, the west is Pojoksari Village, and the east is Tuntang Village. There are two hamlets, 4 RW, and 10 RT in Bejalen Village. According to population data taken from village officials, Bejalen Village has 1903 residents, with 940 men and 963 women.

From the discussion above, the researcher wants to know more about the form of environmental determinism that occur between the coastal communities of Rawa Pening, especially the residents of Bejalen Village and the existence of Rawa Pening Lake, such as community activities that occur, the equipment used, social organizations, local knowledge, and traditions formed in society. 


\section{Methods}

After a brief explanation of environmental determinism and Bejalen Village, to find out more about the forms of environmental determinism between Bejalen Village and Rawa Pening Lake, it is necessary to use several methodologies to collect data. Researches will help us with qualitative methods and data collection methods, namely participant observation, in-depth and informal interviews, ethnographic field notes, and literature studies. DeMUNCK and SOBO (1998) describe participant observation as the primary method used by anthropologists doing fieldwork. Fieldwork involves "actively looking, improving memory, informal interviewing, writing detailed field notes, and perhaps most importantly, patience" [8]. In-depth interviewing is a qualitative research technique involving intensive individual interviews with a few respondents to explore their perspectives on a particular idea, program, or situation [7]. Ethnographic field notes are considered the most crucial field text collection method in qualitative research and a primary field text for an ethnographic study. Writing the field notes is virtually a significant way for the researcher to record the data [1]. Researches will go directly to the field and participate in community activities to get an emic perspective as a Bejalen Village community. In participating in these activities, researchers will conduct in-depth but informal interviews so that the community can carry out their activities. When conducting activities and informal in-depth interviews, researchers can write the results of observations and accounts from the informants, which will be in the form of ethnographic diaries. Do not also forget to use previous research literature studies as data reinforcement.

\section{Result and Discussion: Forms of Environmental Determinism}

\subsection{Livelihoods by region}

Hamlet in Bejalen is divided into two areas, namely West Bejalen and East Bejalen. East Bejalen intersects with JLA (Ambarawa Ring Road), and East Bejalen intersects directly with Lake Rawa Pening. The West Bejalen and East Bejalen regions have different levels of elevation. East Bejalen has a lower elevation level than the West Bejalen area. As a result of these different elevation levels, the East Bejalen area is often flooded due to Lake Rawa Pening. The location of different areas also results in different livelihoods for residents.

The Eastern Region is an area that is in direct contact with Lake Rawa Pening while the West is in contact with JLA (Ambarawa Ring Road). According to observations, activities or livelihoods refer to these two locations. East Bejalen, which is in direct contact with Lake Rawa Pening, works as a fisherman. West Bejalen. This does not touch directly with Lake Rawa Pening; the people have activities or work as farm labourers and factory workers.

\subsection{Livelihood groups}

There are five community groups in Bejalen Village: the branjang group, the karamba group, the catch fishermen group, the rice planting group, and the prestasami group. Branjang is catching fish with nets with assistive tools such as ontel or paddles to lift the net. Karamba is a fish breeding tool that is placed in the middle of a lake. The function of karamba is to cultivate the fish. Catch fishers are catching fish in the lake using tools such as fishing rods or fish traps. Rice planting is an activity like farming, such as cultivating the land or ploughing the fields, planting seeds, applying fertilizers, weeding or eradicating 
weeds, monitoring, and finally harvesting. Prestasami or the PKK group has activities such as fish middlemen and other activities. Each group has its routine agenda and aims to gather and coordinate the activities of its member, especially in the field of the groups.

\subsection{Equipment}

In their activities, the community is assisted with equipment to make their work easier. After making observations, there are several tools used related to the existence of Lake Rawa Pening. Boats are the main transportation used by fishermen to carry out their activities. Generally, the boat used is a type of outboard boat or boat made of assembled wood. The type of wood used is bengkirai wood or Kalimantan wood. The sizeable outboard boat can accommodate 4-5 people, and the small one can only accommodate 1-3 people. The boat can be moved using an engine or paddle. The engines are typically used for large outboard boats, and the paddle is used for small outboard boats.

There are various kinds of fishing gear used by the Bejalen people, namely fishing rods, nets, spears, fish traps, and rifles. A fishing rod is a fishing tool that fishers most widely use. Especially catch fishermen groups. Netas are fishing tools in the form of woven nets. The function of the nets themselves is to catch a large number of fish. A fish trap is a type of fishing gear that is placed in specific places to catch fish. Fish traps have a variety of shapes but are often used in the form of blocks with layers of netting. Spears and rifles are fishing tools that fishers rarely use in Bejalen village. The spear is shaped like a fork. The spear's handle is made of wood, and the tip of the spear is iron with sharp tips. The rifle used to catch fish is an air rifle with a thin iron bar bullet tied with a nylon rope. The purpose of the rope is to draw bullets.

Lake Rawa Pening is a means for surrounding residents to catch fish and breed them. The tools commonly used by residents of the lakeside, especially Bejalen Village, are branjang and karamba. Branjang is a tool for catching fish, and karamba is a medium for breeding fish. In Lake Rawa Pening itself, there are many branjang and karamba built by residents. Every citizen has the right to make it because Lake Rawa Pening is a public water area, everyone has the right to use it. Branjang is made of bamboo, which is assembled into one, and there is a hut as a place to pull out the nets and shade. The net is pulled using a pulley, or the villagers call it ontel. The branjang frame is used to protect the nets from water hyacinth plants and to stick the bamboo as a pillar for the establishment of branjang. There are two forms of branjang. Namely the branjang engkel and branjang ganda. The branjang engkel has one box for the netting, while the branjang ganda has two boxes for the nets, and the hut is between the boxes.

Karamba is a place or means of breeding fish. Karamba is made of bamboo woven and given a net as a place for fish to live. The function of the bamboo is as a cage frame, a place to walk. Moreover, a place to attach the nets, while the function of the nets is as a barrier for the fish so that they do not get out of the cage. The karamba in Lake Rawa Pening has 12-20 boxes in each cage plot. Each box is filled with different types of fish and different ages. Generally, the fish raised in karamba are tilapia, giuramy, and pomfret.

\subsection{Knowledge}

The residents of Rawa Pening Lake have local knowledge, which is used daily for daily activities. Local knowledge consists of actual knowledge, expertise, and abilities produced by the community as a social product [2]. Local knowledge possessed by villagers, especially those who work as fisherman, is the appointment of the cardinal directions to avoid the movement of water hyacinth plants (Eichhornia Crassipes) and as a form of vigilance when going to the lake. Catch fisher is a type of fishermen who catches fish using 
fishing rods and fish traps. So that the installed fish trap is not damaged by water hyacinth plants, before placing the trap, it is necessary to predict the direction of the wind. The problem that is often encountered is that the water hyacinth plants that grow in colonies move in the wind and damage the fish traps that have been set by fishermen so that fishers do not get results. Apart from catch fishers, branjang fishers and karamba fishermen take advantage of the wind as a form of vigilance. The dangerous wind that blows into the lake area comes from the west (Tuntang) and east (Sepakung) because it is dangerous. So the fishermen who are already in the middle have to wait for the wind to pass.

\subsection{Tradition}

Bejalen Village has several traditions that are routinely held. Tradition itself means a belief, principle, or way of behaving in society that has been going on for a long time (Cambridge Dictionary). The tradition that exists in Bejalen village, which intersects with the surrounding environment, is the Sedekah Desa. Sedekah Desa has the purpose and meaning that everything obtained or harvested by the community is a direct gift from God; for this reason, sedekah desa is held as a form of public gratitude to God for abundant sustenance in the form of yields or harvested powers. Sedekah desa in Bejalen village is routinely carried out every December and Sabtu Pon (Javanese Calendar). It is held at the end of the year because the people there harvest natural resources, and Sabtu pon means "chasing thieves" so that the village is safe from accidents. The tradition of sedekah desa in Bejalen is carried out for four days with details of the event on Thursday holding joint prayers at their respective places of worship, Friday carrying out village cleaning and eating together, Saturday carrying out salvation and entertainment, Sunday Carrying out healthy walks.

Weweton or the yields given during sedekah desa can vary depending on the region. East Bejalen is directly adjacent to Lake Rawa Pening. The majority of them have jobs as fishers providing alms of agricultural products in the form of fish and West Bejalen, which the majority of its residents work as agricultural labourers. Part of the area is agricultural, so almsgiving crops are in the form of agricultural products.

\section{The Impact of Activities on the Environment}

Activities carried out by the community have an impact on the environment. According to the results of observations made when conducting activities with the residents, Rawa Pening Lake is currently full of many branjang and karamba that have been built by the local community. The existence of karamba and branjang is also a place for the moving water hyacinth plants. The subsequent impact which has an impact is the amount of garbage inundated in Lake Rawa Pening. Existing waste results from shipments upstream to downstream of the river and fishing activities because fishers bring supplies from home to the middle of the lake.

\section{Conclusion}

Environmental determinism is an understanding that the environment determines the actions, culture, and characteristics of society. Lake Rawa Pening accidentally forms a culture for the coastal community, especially the people of Bejalen Village. The forms of environmental determinism that occur in Bejalen Village are the livelihoods by region, groups based on livelihoods, equipment, traditions, and local knowledge. 


\section{Acknowledgement}

This research was conducted in Bejalen village, Ambarawa and funded by the Faculty of Humanities, Diponegoro University. This research was assisted by the local community, namely Mbah Pari who had provided lodging and melas and also Bejalen Village officials who had allowed me to research the forms of environmental determinism in Bejalen Village.

\section{Reference}

1. D. P. Adhikari, Ethnographic Fieldnote Writin: Methodological Challenges in the 21 st Century, Dhaulagiri Journal of Sociology and Anthropology, 12(1990), 98-106 (2020)

2. C. Antweiler, Local knowledge and local knowing: An anthropological analysis of contested "cultural products" in the context of development, Anthropos, 93(4-6), 469494 (1998)

3. M. R. Dove, Perception of volcanic eruption as agent of change on Merapi volcano, Central Java, Journal of Volcanology and Geothermal Research, 172(3-4), 329-337 (2008)

4. K. Fekadu, The paradox in environmental determinism and possibilism: A literature review, Journal of Geography and Regional Planning, 7(7), 132-139 (2014)

5. S. Frenkel, Geography, empire, and environmental determinism, Geographical Review, 82(2), 143-153 (1992)

6. G. L. Hardin, (2009) Environmental Determinism: Broken Paradigm or Viable Perspective?, Retrieved from: http://newsroom.unfccc.int/unfccc-newsroom/finalecop21/

7. D. Jacobvitz, M. Curran, N. Moller, Measurement of adult attachment: The place of self-report and interview methodologies, Attachment and Human Development, 4(2), 207-215 (2002)

8. B. B. Kawulich, Participant observation as a data collection method, Forum Qualitative Sozialforschung, 6(2), (2005)

9. M. Al. Mujabuddawat, Kejayaan Kesultanan Buton Abad Ke-17 \& 18 dalam Tinjauan Arkeologi Ekologi, Kapata Arkeologi, 11(1), 21 (2016)

10. M. F. Riza,.Antropologi Keharaman Babi Bagi Kaum Muslim dan Yahudi (Issue September), (2019) 